\title{
Amplification of Elementary Surface Reaction Steps on Transition Metal Surfaces using Liquid Crystals: Dissociative Adsorption and Dehydrogenation
}

\author{
Huaizhe Yu ${ }^{\dagger,+}$, Tibor Szilvási ${ }^{\ddagger+}$, Kunlun Wang ${ }^{\#}$, Jake I. Gold ${ }^{\ddagger}$, Nanqi Bao ${ }^{\dagger}$, Robert J. Twieg ${ }^{\#}$, \\ Manos Mavrikakis* $*$ and Nicholas L. Abbott*,†
}

'Robert Frederick Smith School of Chemical and Biomolecular Engineering, Cornell University, 1 Ho Plaza, Ithaca, New York 14853, United States

tDepartment of Chemical and Biological Engineering, University of Wisconsin-Madison, 1415 Engineering Drive, Madison, Wisconsin 53706, United States

\#Department of Chemistry and Biochemistry, Kent State University, 1175 Risman Drive, Kent, Ohio 44242, United States

${ }^{+}$H.Y. and T.S. contributed equally to this work.

\section{Computational methods}

\section{Calculation of phase diagram for $\mathrm{Cl}$ adsorption on $\mathrm{Au}(111)$}

We built on the approach described by Bollinger et $\mathrm{al}^{1}$ and Xu et $\mathrm{al}^{2}$. We calculated the grand potential per surface area $(\Omega)$ for the $\mathrm{Cl}$ adlayer at each investigated surface coverage:

$$
\Omega(\mathrm{p}, \mathrm{T})=\left[\mathrm{G}_{\mathrm{nCl}+\text { substrate }}-\mathrm{G}_{\text {substrate }}-\mathrm{n} \mu_{\mathrm{Cl}} \mathrm{I}^{*} / \mathrm{A}\right.
$$

where $\mathrm{G}_{\mathrm{nCl}+\text { substrate }}$ is the Gibbs free energy of the $\mathrm{Cl}$ covered $\mathrm{Au}(111), \mathrm{G}_{\text {substrate }}$ is the Gibbs free energy of clean $\mathrm{Au}(111), \mu_{\mathrm{Cl}}$ is the chemical potential of adsorbed $\mathrm{Cl}$ ('*' denotes adsorption), $\mathrm{n}$ is the number of adsorbed $\mathrm{Cl}$ atoms, and $\mathrm{A}$ is surface area of the unit cell. We assumed equilibrium between the gas phase and the surface, and thus the chemical potential of adsorbed $\mathrm{Cl}$ is equal to the chemical potential of $1 / 2 \mathrm{Cl}_{2}(\mathrm{~g})$ $\left(\mu_{\mathrm{C} 1^{*}}=1 / 2 \mu_{\mathrm{C} 12}\right) . \mu_{\mathrm{C} 12}$ can be expressed as

$$
\begin{gathered}
\mu_{\mathrm{C} 12}(\mathrm{p}, \mathrm{T})=\mathrm{H}_{\mathrm{Cl} 2}\left(\mathrm{p}_{0}, \mathrm{~T}\right)-\mathrm{TS}_{\mathrm{Cl} 2}\left(\mathrm{p}_{0}, \mathrm{~T}\right)+\mathrm{kT} \ln \left(\mathrm{p} / \mathrm{p}_{0}\right) \\
\mu_{\mathrm{Cl} 2}(\mathrm{p}, \mathrm{T})=\mathrm{E}_{\mathrm{Cl} 2}+\left[\mathrm{H}_{\mathrm{Cl} 2}\left(\mathrm{p}_{0}, \mathrm{~T}=0 \mathrm{~K}\right)-\mathrm{E}_{\mathrm{Cl} 2}\right]+\left[\mathrm{H}_{\mathrm{Cl} 2}\left(\mathrm{p}_{0}, \mathrm{~T}\right)-\mathrm{H}_{\mathrm{Cl} 2}\left(\mathrm{p}_{0}, \mathrm{~T}=0 \mathrm{~K}\right)\right]-\mathrm{TS}_{\mathrm{Cl} 2}\left(\mathrm{p}_{0}, \mathrm{~T}\right)+\mathrm{kT} \ln \left(\mathrm{p} / \mathrm{p}_{0}\right)
\end{gathered}
$$

where $\mathrm{E}_{\mathrm{Cl} 2}$ is the total energy of a $\mathrm{Cl}_{2}$ molecule in the gas phase, $\mathrm{H}_{\mathrm{Cl} 2}\left(\mathrm{p}_{0}, \mathrm{~T}=0 \mathrm{~K}\right)$ is the enthalpy of $\mathrm{Cl}_{2}(\mathrm{~g})$ at standard pressure $\mathrm{p}_{0}(101325 \mathrm{~Pa})$ and $0 \mathrm{~K}, \mathrm{H}_{\mathrm{Cl}}\left(\mathrm{p}_{0}, \mathrm{~T}\right)$ is the enthalpy of $\mathrm{Cl}_{2}(\mathrm{~g})$ at standard pressure $\mathrm{p}_{0}$ $(101325 \mathrm{~Pa})$ and temperature $\mathrm{T}$, and $\mathrm{S}_{\mathrm{Cl} 2}\left(\mathrm{p}_{0}, \mathrm{~T}\right)$ is the entropy of $\mathrm{Cl}_{2}$, while $\left[\mathrm{H}_{\mathrm{Cl}}\left(\mathrm{p}_{0}, \mathrm{~T}=0 \mathrm{~K}\right)-\mathrm{E}_{\mathrm{Cl} 2}\right]$ is the zero-point energy of $\mathrm{Cl}_{2}$ and $\left[\mathrm{H}_{\mathrm{Cl}}\left(\mathrm{p}_{0}, \mathrm{~T}\right)-\mathrm{H}_{\mathrm{Cl}}\left(\mathrm{p}_{0}, \mathrm{~T}=0 \mathrm{~K}\right)\right]$ is the temperature dependence of $\mathrm{Cl}_{2}$ enthalpy. Thermodynamic correction terms $\left(\left[\mathrm{H}_{\mathrm{Cl} 2}\left(\mathrm{p}_{0}, \mathrm{~T}=0 \mathrm{~K}\right)-\mathrm{E}_{\mathrm{Cl} 2}\right],\left[\mathrm{H}_{\mathrm{Cl} 2}\left(\mathrm{p}_{0}, \mathrm{~T}\right)-\mathrm{H}_{\mathrm{Cl} 2}\left(\mathrm{p}_{0}, \mathrm{~T}=0 \mathrm{~K}\right)\right]\right.$, and $\left.\mathrm{S}_{\mathrm{Cl} 2}\left(\mathrm{p}_{0}, \mathrm{~T}\right)\right)$ were calculated directly from analysis of the vibrational, rotational, and translational degrees of freedom of a $\mathrm{Cl}_{2}$ molecule in vacuum.

$\mathrm{G}_{\mathrm{nCl}+\text { substrate }}$ and $\mathrm{G}_{\text {substrate }}$ can be expressed similarly to $\mu_{\mathrm{Cl} 2}(\mathrm{p}, \mathrm{T})$, however we neglected the pressure dependence of $\mathrm{G}_{\mathrm{nCl}+\text { substrate }}$ and $\mathrm{G}_{\text {substrate }}$ and the vibrational contribution of the substrate to the thermodynamic correction terms. Both assumption are justified because previous analyses showed the relatively small contribution of these terms, and additionally, error cancellation is expected to further reduce the error originating from these assumptions. ${ }^{1}$ Accordingly,

$\mathrm{G}_{\mathrm{nCl}+\text { substrate }}=\mathrm{E}_{\mathrm{nCl}+\text { substrate }}+\left[\mathrm{H}_{\mathrm{nCl}+\text { substrate }}(\mathrm{T}=0 \mathrm{~K})-\mathrm{E}_{\mathrm{nCl}+\text { substrate }}\right]+\left[\mathrm{H}_{\mathrm{nCl}+\text { substrate }}(\mathrm{T})-\mathrm{H}_{\mathrm{nCl}+\text { substrate }}(\mathrm{T}=0 \mathrm{~K})\right]-\mathrm{TS}_{\mathrm{nCl}+\text { substrate }}(\mathrm{T})$ where $\mathrm{E}_{\mathrm{nCl}+\text { substrate }}$ is the energy of the $\mathrm{Cl}$ covered $\mathrm{Au}(111), \mathrm{H}_{\mathrm{nCl}+\text { substrate }}(\mathrm{T}=0 \mathrm{~K})$ is the enthalpy of the $\mathrm{Cl}$ covered $\mathrm{Au}(111)$ at zero temperature, $\mathrm{H}_{\mathrm{nCl}+\text { substrate }}(\mathrm{T})$ is the enthalpy of the $\mathrm{Cl}$ covered $\mathrm{Au}(111)$ at temperature 
$\mathrm{T}$, and $\mathrm{S}_{\mathrm{nCl}+\text { substrate }}(\mathrm{T})$ is the entropy of the $\mathrm{Cl}$ covered $\mathrm{Au}(111)$ at temperature $\mathrm{T}$, while $\left[\mathrm{H}_{\mathrm{nCl}+\text { substrate }}(\mathrm{T}=0 \mathrm{~K})\right.$ - $\left.\mathrm{E}_{\mathrm{nCl}+\text { substrate }}\right]$ is the zero point energy contribution of the $\mathrm{Cl}$ overlayer on $\mathrm{Au}(111)$ and $\left[\mathrm{H}_{\mathrm{nCl}+\text { substrate }}(\mathrm{T})\right.$ $\left.\mathrm{H}_{\mathrm{nCl}+\text { substrate }}(\mathrm{T}=0 \mathrm{~K})\right]$ is the temperature dependence of the enthalpy of the $\mathrm{Cl}$ overlayer on $\mathrm{Au}(111)$. Thermodynamic correction terms, $\left[\mathrm{H}_{\mathrm{nCl}+\text { substrate }}(\mathrm{T}=0 \mathrm{~K})-\mathrm{E}_{\mathrm{nCl}+\text { substrate }}\right],\left[\mathrm{H}_{\mathrm{nCl}+\text { substrate }}(\mathrm{T})-\mathrm{H}_{\mathrm{nCl}+\text { substrate }}(\mathrm{T}=0 \mathrm{~K})\right]$, and $\mathrm{S}_{\mathrm{nCl}+\text { substrate }}(\mathrm{T})$, were calculated from the analysis of the vibrational, rotational, and translational degrees of freedom of the $\mathrm{Cl}$ overlayer on $\mathrm{Au}(111)$. Additionally, because of the abovementioned assumptions, $\mathrm{G}_{\text {substrate }}=\mathrm{E}_{\text {substrate. }}$.

We evaluated 1/3, 4/9, 1/2,5/9, and 2/3 ML Cl coverages on $\mathrm{Au}(111)$ to construct the phase diagram. Our choice for different surface coverages was motivated by previous experimental studies confirmed the presence of $1 / 3 \mathrm{ML} \mathrm{Cl}$ coverage on $\mathrm{Au}(111)$ in ultra-high vacuum (UHV) experiments. ${ }^{3,4}$ Additionally, in our experimental setup, the $\mathrm{Cl}_{2}$ partial pressure is above $0.1 \mathrm{~Pa}$, which is at least six orders of magnitude higher than that in UHV experiments. We note that previous works suggested that high $\mathrm{Cl}_{2}$ partial pressure can indeed induce further $\mathrm{Cl}$ adsorption, resulting in higher than $1 / 3 \mathrm{ML}$ coverages, but the resulting overlayer structures and potential reconstructions of the surface are still unclear. ${ }^{3,4}$ For this initial study, we neglected the potential reconstruction of the surface, and we only investigated $\mathrm{Au}(111)$ surfaces. We found that the optimal $\mathrm{Cl}$ coverage under our experimental conditions (ambient temperature and $1 \mathrm{ppm} \mathrm{Cl}_{2}$ ) is $1 / 2$ $\mathrm{ML} \mathrm{Cl}$ coverage. Figure $\mathrm{S} 1$ shows the obtained most favorable $1 / 2 \mathrm{ML} \mathrm{Cl}$ covered $\mathrm{Au}(111)$ surface. All $\mathrm{Cl}$ atoms occupy bridge sites, each $\mathrm{Cl}$ atom having two neighboring $\mathrm{Au}$ atoms, while all surface $\mathrm{Au}$ atoms have only one $\mathrm{Cl}$ adsorbate.

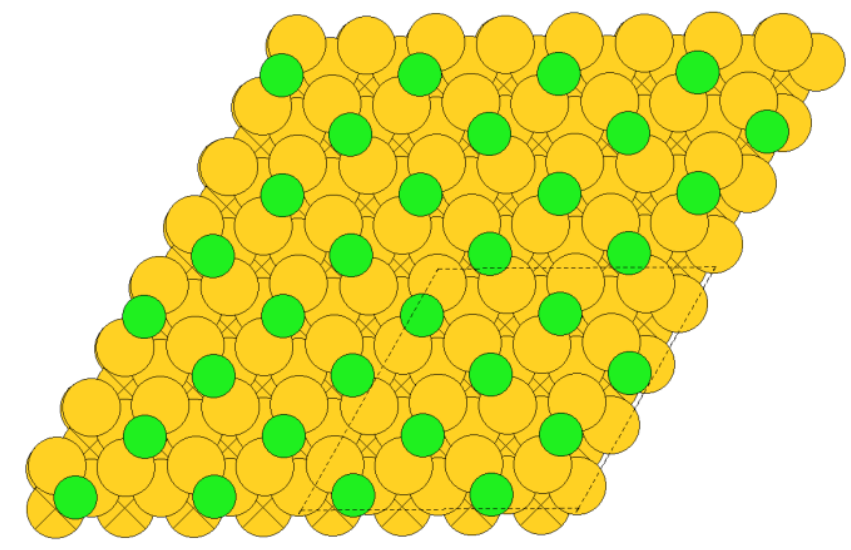

Figure S1. Calculated structure of $1 / 2 \mathrm{ML} \mathrm{Cl}$ covered $\mathrm{Au}(111)$ surface. Green and yellow colors indicate $\mathrm{Cl}$ and $\mathrm{Au}$ atoms, respectively. Crossed atoms were not allowed to relax not moved during energy minimization. Dashed lines indicate the unit cell borders. Multiple unit cells are shown to recognize surface pattern of $\mathrm{Cl}$ adatoms.

\section{Synthesis}

\section{Synthesis of 4'-cyanobiphenyl-4-carboxylic acid (CBCA, Scheme 1). ${ }^{5}$}

A $100 \mathrm{ml}$ round bottom flask fitted with a magnetic stir bar was charged with 4-bromobenzoic acid (2.01, $10.0 \mathrm{mmol})$ and a mixed solvent comprising $\mathrm{H}_{2} \mathrm{O}(6.0 \mathrm{ml})$, , 4 -dioxane $(15.0 \mathrm{ml})$ and $\mathrm{Pd}\left(\mathrm{PPh}_{3}\right)_{4}(115 \mathrm{mg}$, $1.0 \mathrm{~mol} \%$ ). To this suspension was added 4-cyanophenylboronic acid (1.70 g, $15.0 \mathrm{mmol}, 1.5 \mathrm{equiv}$.) and potassium carbonate (2.76 g, $20.0 \mathrm{mmol}, 2.0$ equiv.). This mixture was refluxed and the reaction was monitored by thin layer chromatography (TLC) until completion. After cooling to room temperature, the mixture was filtered through a Celite pad and the pad was washed with a 1:1 mixture of $\mathrm{H}_{2} \mathrm{O} /$ methanol (400 $\mathrm{ml})$. The filtrate was then acidified with $10 \%$ hydrochloric acid dropwise until $\mathrm{pH}=4-4.5$. The precipitate 
was collected by vacuum filtration and washed with water. The crude product was then recrystallized from methanol to afford white crystals $\left(1.1 \mathrm{~g}, 50 \% \text { ). K } 268 \mathrm{~N} 315 \mathrm{I} \text { (ref. K } 266 \mathrm{~N} 315 \mathrm{I}^{6}\right)^{1} \mathrm{H}$ NMR (DMSO-d 6 , $400 \mathrm{MHz}) \delta(\mathrm{ppm}): 13.13(\mathrm{~s}, 1 \mathrm{H}), 8.05(\mathrm{~m}, 2 \mathrm{H}), 7.98(\mathrm{~m}, 4 \mathrm{H}), 7.91(\mathrm{~m}, 2 \mathrm{H})$.

\section{Synthesis of 4'-cyanobiphenyl-4-carboxylic methyl ester (CBCM). ${ }^{7}$}

In a $50 \mathrm{ml}$ round bottom flask fitted with a magnetic stir bar, 4'-cyanobiphenyl-4-carboxylic acid (400 $\mathrm{mg}$ ) was dissolved in methanol $(20.0 \mathrm{ml})$ followed by the addition of a catalytic amount of concentrated sulfuric acid. The resulting mixture was stirred at reflux overnight. TLC analysis indicated that the starting acid was consumed. The reaction was cooled, and the precipitate was filtered by vacuum to give a white solid. This crude product was then recrystallized from ethanol to afford white crystals (330 mg, 78\%). GC-MS: 237.13 found 237.25 calc. ${ }^{1} \mathrm{H} \mathrm{NMR}\left(\mathrm{CDCl}_{3}, 400 \mathrm{MHz}\right) \delta(\mathrm{ppm}): 8.13(\mathrm{~m}, 2 \mathrm{H}), 7.75(\mathrm{~m}, 2 \mathrm{H}), 7.72(\mathrm{~m}, 2 \mathrm{H}), 7.66$ $(\mathrm{m}, 2 \mathrm{H}), 3.95(\mathrm{~s}, 3 \mathrm{H}) ;{ }^{13} \mathrm{C} \mathrm{NMR}\left(\mathrm{CDCl}_{3}, 100 \mathrm{MHz}\right) \delta(\mathrm{ppm}): 166.6,144.4,143.4,132.7,130.4,130.2$, $127.9,127.3,118.7,111.8,52.3$.

\section{Synthesis of sodium 4'-cyanobiphenyl-4-carboxylate (CBCNa). ${ }^{8}$}

In a $50 \mathrm{ml}$ round bottom flask fitted with a magnetic stir bar, 4'-cyanobiphenyl-4-carboxylic acid (446 mg, $2.0 \mathrm{mmol})$ was dissolved in ethanol $(10.0 \mathrm{ml})$. To the resulting suspension was added a solution of $\mathrm{t}-\mathrm{BuONa}$ $(192 \mathrm{mg}, 2.0 \mathrm{mmol})$ in $10.0 \mathrm{ml}$ ethanol dropwise. Once the addition was complete, the resulting mixture was stirred at room temperature overnight. The precipitate was filtered by vacuum and washed with ethanol $(3 \times 5.0 \mathrm{ml})$ and diethyl ether $(3 \times 5.0 \mathrm{ml})$. The desired product was then obtained as an off-white solid (410 $\mathrm{mg}, 84 \%) . \mathrm{MP}>300{ }^{\circ} \mathrm{C} .{ }^{1} \mathrm{H}$ NMR (DMSO-d $\left.6,400 \mathrm{MHz}\right) \delta(\mathrm{ppm}): 7.96(\mathrm{~d}, J=8.0 \mathrm{~Hz}, 2 \mathrm{H}), 7.90$ (m, 4H), $7.65(\mathrm{~d}, J=8.0 \mathrm{~Hz}, 2 \mathrm{H}) ;{ }^{13} \mathrm{C}$ NMR (DMSO-d $\left.6,100 \mathrm{MHz}\right) \delta(\mathrm{ppm}): 169.1,145.3,141.9,138.4,133.3,130.2$, $128.0,126.3,119.4,110.2$.
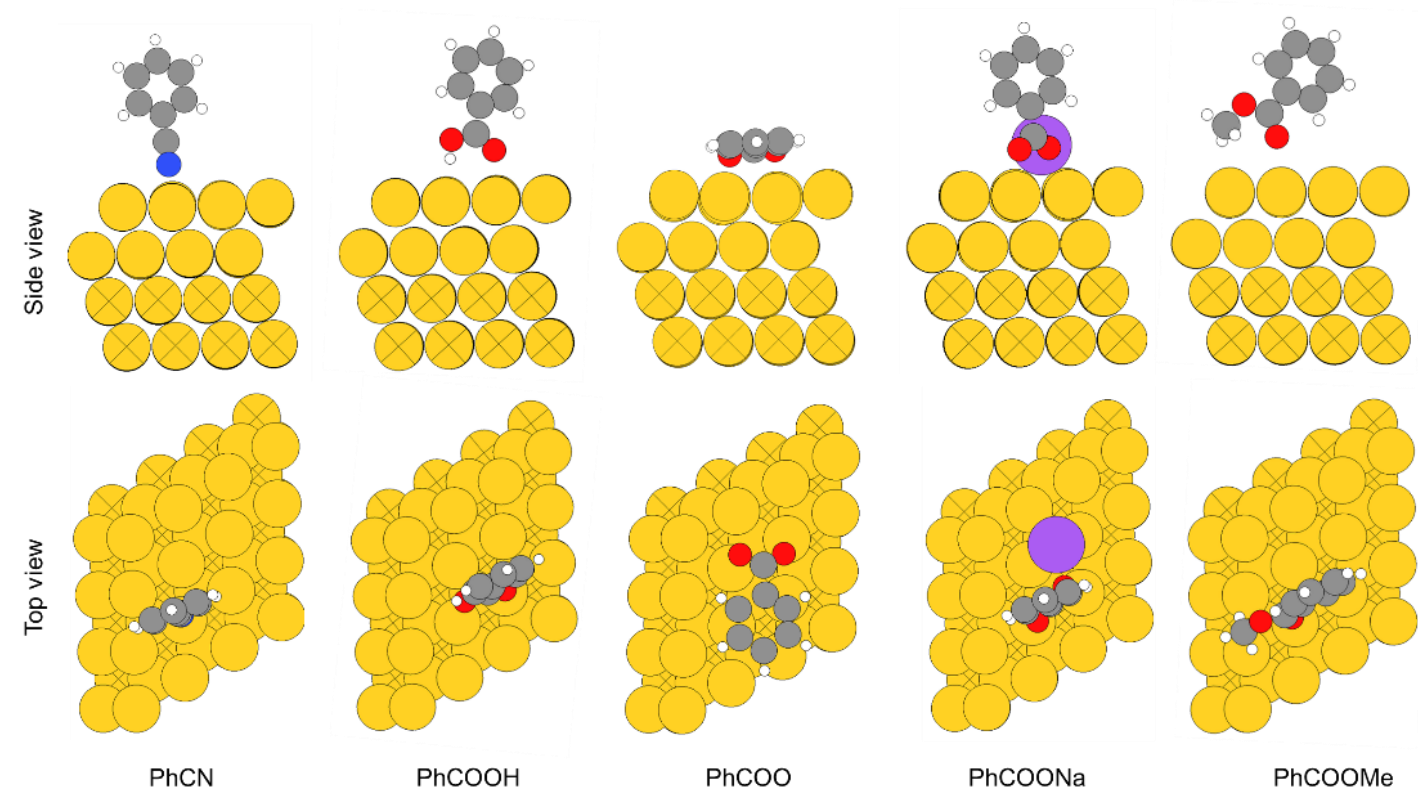

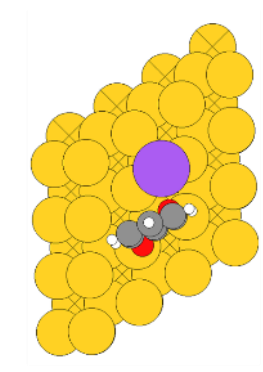

PhCOONa

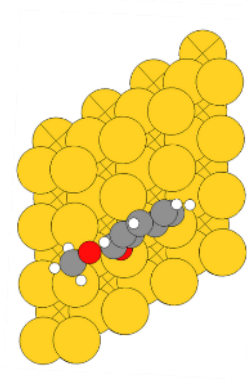

PhCOOMe

Figure S2. Minimum energy, but not the most preferred structures, for $\mathrm{PhCN}, \mathrm{PhCOOH}, \mathrm{PhCOO}$, $\mathrm{PhCOONa}$ and PhCOOMe on $\mathrm{Au}(111)$ slab. White, grey, blue, red, purple and yellow colors indicate $\mathrm{H}, \mathrm{C}$, $\mathrm{N}, \mathrm{O}, \mathrm{Na}$ and $\mathrm{Au}$ atoms, respectively. Crossed $\mathrm{Au}$ (yellow) atoms were kept fixed during geometry optimization. 


\section{Additional discussion.}

\section{Analysis of the orientation of $\mathrm{PhCN}$ on $\mathrm{Cl}$ covered $\mathrm{Au}(111)$}

We investigated the binding properties of $\mathrm{PhCN}$ on $\mathrm{Cl}$ covered $\mathrm{Au}(111)$ by evaluating the binding energy of $\mathrm{PhCN}$ in perpendicular and parallel orientations. We applied 1/3 $\mathrm{ML} \mathrm{Cl}$ coverage in a $3 \times 3$ unit cell of $\mathrm{Au}(111)$. We found that $\mathrm{PhCN}$ binding in parallel orientation is $-0.72 \mathrm{eV}$ (Figure S3a) while in perpendicular orientation is $-0.39 \mathrm{eV}$ (Figure S3b). Thus we predict that parallel orientation is still preferred on $\mathrm{Cl}$ covered $\mathrm{Au}(111)$ surface similar to clean $\mathrm{Au}(111)$. We also note that higher than 1/3 ML Cl coverage is expected to behave similarly.

(a)

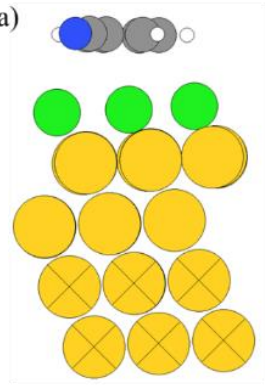

Side view

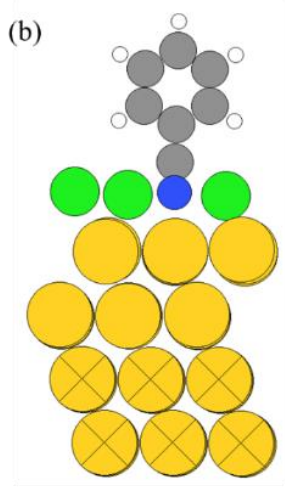

Side view

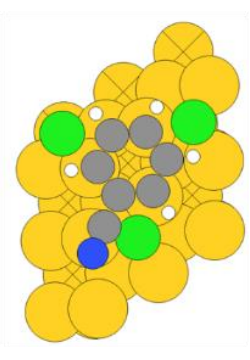

Top view

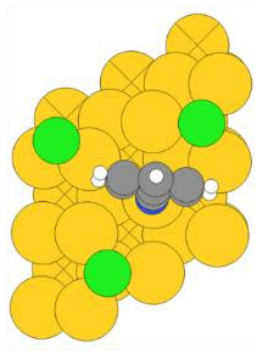

Top view

Figure S3. Calculated structure of $\mathrm{PhCN}$ on 1/3 monolayer $\mathrm{Cl}$ pre-covered $\mathrm{Au}(111)$ surface in (a) parallel and (b) perpendicular orientation. White, grey, green, red, and yellow colors indicate $\mathrm{H}, \mathrm{C}, \mathrm{Cl}, \mathrm{O}$ and $\mathrm{Au}$ atoms, respectively. Crossed atoms were not allowed to relax not moved during energy minimization. 
(a)

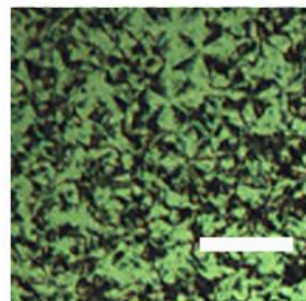

(b)

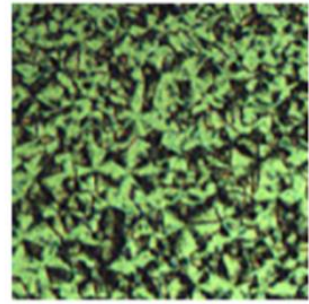

(c)

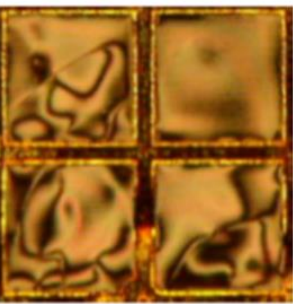

(d)

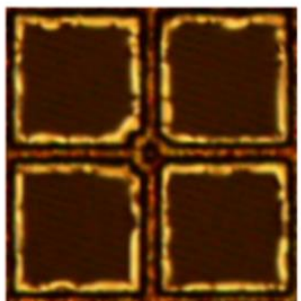

Figure S4. Optical micrographs (crossed polars) of (a) 5CB sandwiched between two gold films, (b) CBCA-5CB $\left(\mathrm{C}_{\mathrm{CBCA}}=0.1 \mathrm{~mol} \%\right)$ sandwiched between two borosilicate surfaces, $(\mathrm{c}) \mathrm{CBCA}-5 \mathrm{CB}\left(\mathrm{C}_{\mathrm{CBCA}}=\right.$ $0.1 \mathrm{~mol} \%)$ on $\mathrm{Si}$ surface, (d) CBCA-5CB $\left(\mathrm{C}_{\mathrm{CBCA}}=0.1 \mathrm{~mol} \%\right)$ on gold surface deposited on Si surface. Scale bar in (a): $100 \mu \mathrm{m}$.

(a)

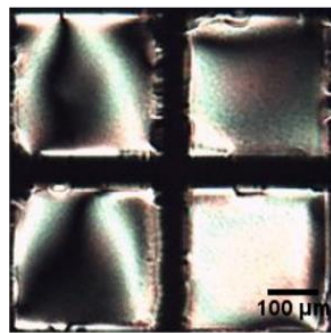

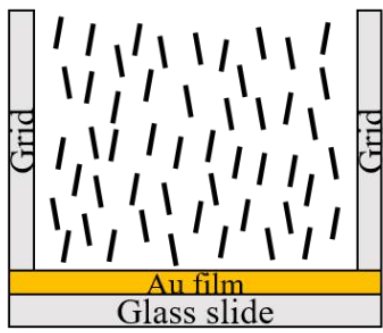

(b)
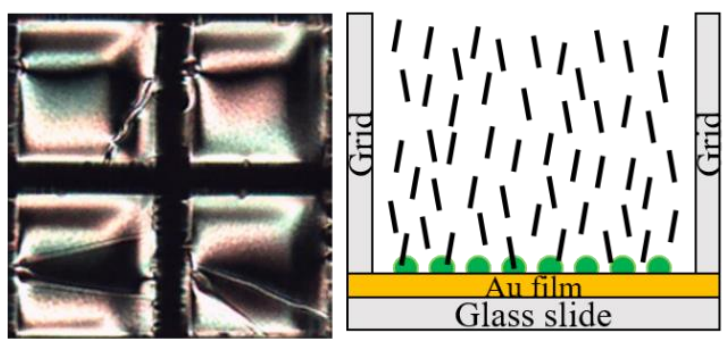

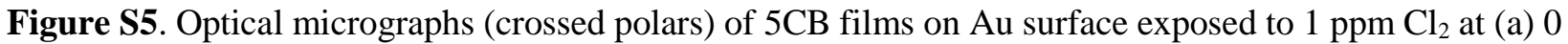
min (b) 30 mins. A schematic representation of the LCs is shown to the side of each optical image. Green circles indicate the adsorbed $\mathrm{Cl}$ atoms. Black lines indicate the director of LCs. Scale bar: $100 \mu \mathrm{m}$.

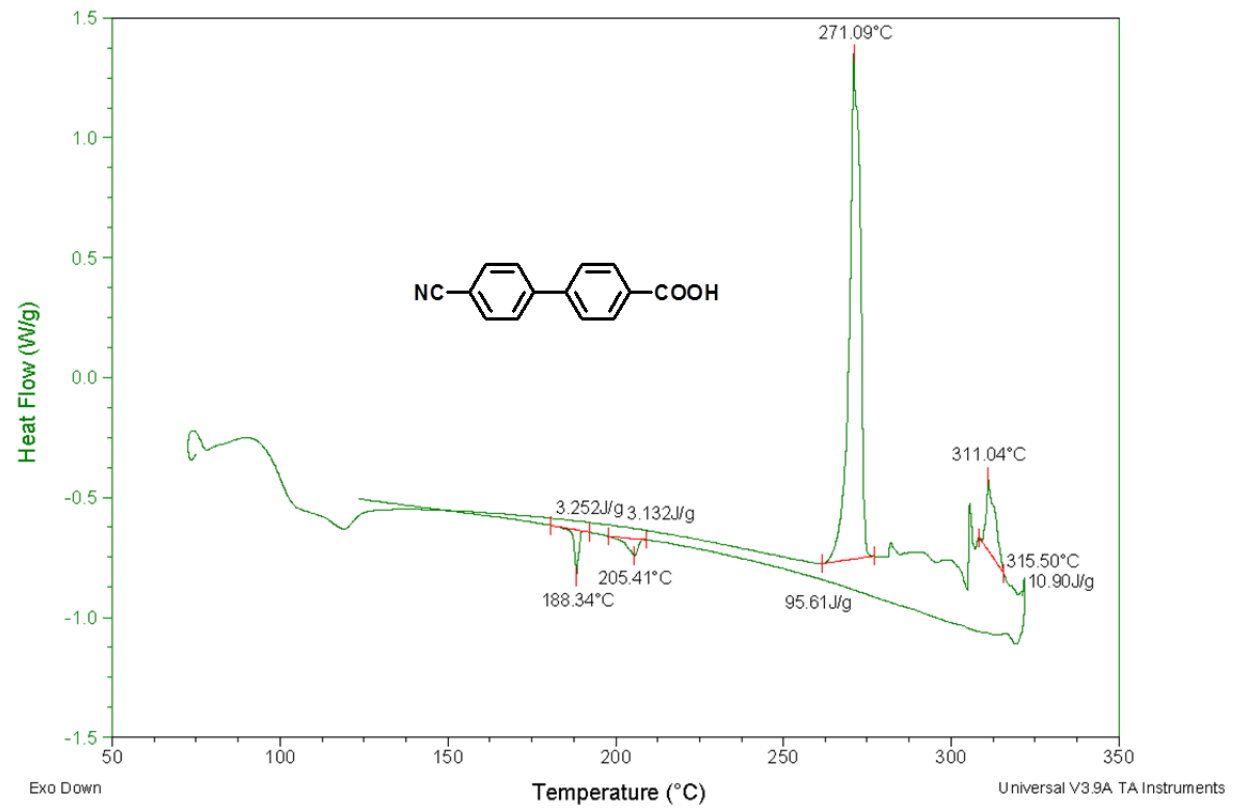

Figure S6. Differential Scanning Calorimetry (DSC) for CBCA. 


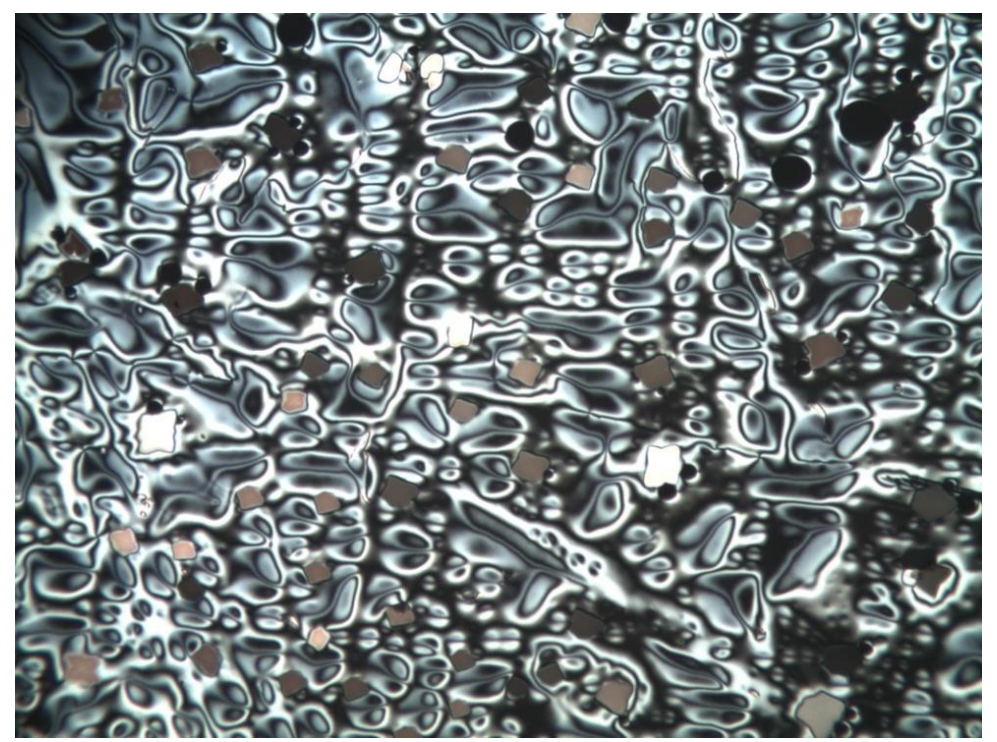

Figure S7. Optical micrographs (crossed polars) for CBCA at $314{ }^{\circ} \mathrm{C}$.

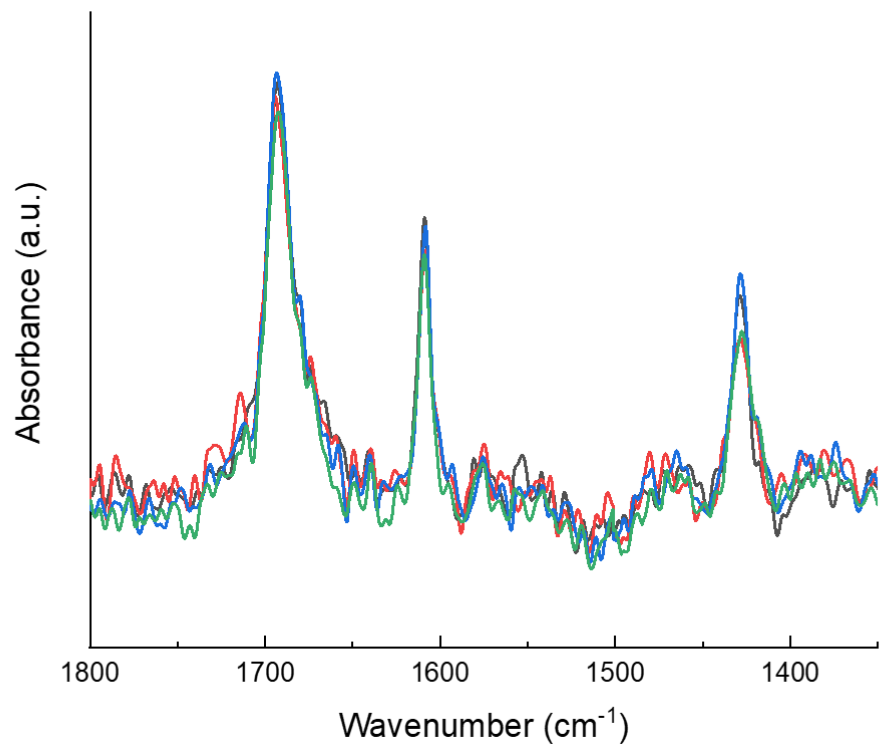

Figure S8. PM-IRRAS of nanometer-thick layers of CBCA on gold films. 


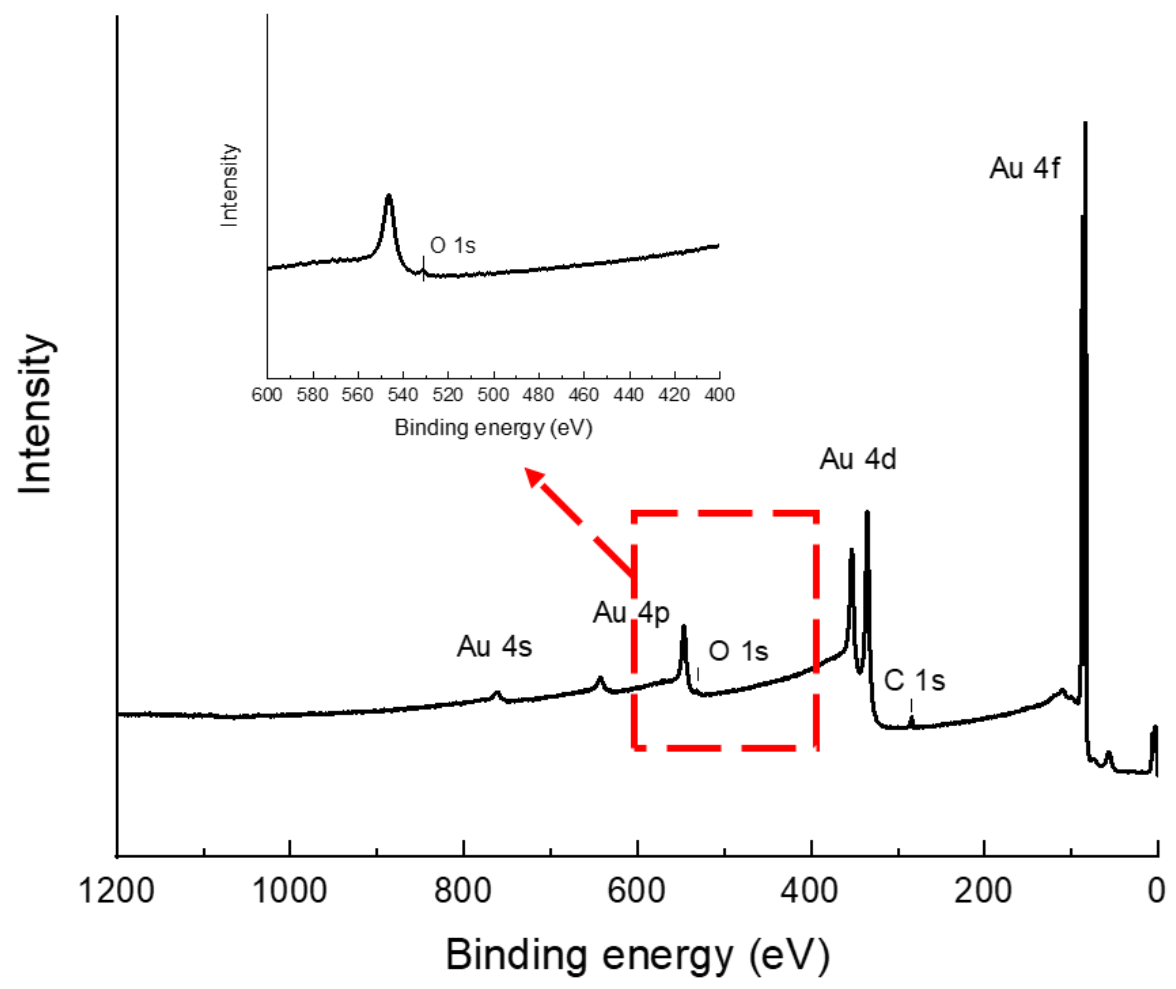

Figure S9. XPS characterization of gold films.

(a)

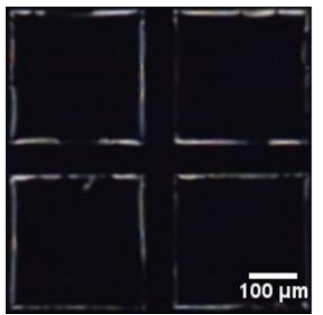

(b)

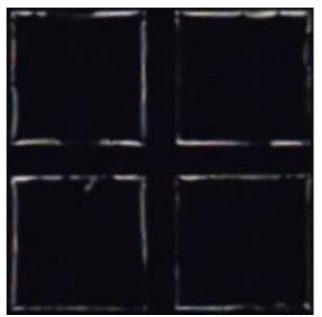

(c)

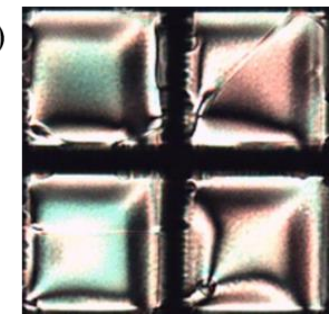

Figure S10. Optical micrographs (crossed polars) of LC films comprising CBCA-5CB of (a) $C_{\mathrm{CBCA}}=0.005$ $\mathrm{mol} \%$, (b) $C_{\mathrm{CBCA}}=0.002 \mathrm{~mol} \%$ and (c) $C_{\mathrm{CBCA}}=0.001 \mathrm{~mol} \%$ on a gold surface. Scale bar: $100 \mu \mathrm{m}$.

\section{Evaluation of the CBCA coverage on gold surface}

We first start our evaluation of the relative surface coverage of 5CB and CBCA-derived carboxylate on $\mathrm{Au}(111)$ by calculating equilibrium constant based on their relative $\mathrm{BE}$. We calculate $\mathrm{BE}$ of $\mathrm{PhCN}$ and $\mathrm{PhCOO}$, surrogates of 5CB and CBCA-derived carboxylate, to be -0.91 and $-1.15 \mathrm{eV}$ (Table 1), respectively. The difference between the $\mathrm{BE}$ of $\mathrm{PhCN}$ and $\mathrm{PhCOO}$ is $0.24 \mathrm{eV}$ in favor of $\mathrm{PhCOO}$, which indicates the dominance of $\mathrm{PhCOO}$ on the surface as $0.06 \mathrm{eV}$ difference in $\mathrm{BE}$ results in one order of magnitude difference in equilibrium constant at room temperature. Using the binding energy listed above and Table 1, we estimate the equilibrium constant of the process $\mathrm{PhCOO}+\mathrm{PhCN}-\mathrm{Au} \rightarrow \mathrm{PhCN}+\mathrm{PhCOO}-\mathrm{Au}$ by 
neglecting the entropy change. By solving the following equation, $\Delta G=B E_{P h C N}-B E_{P h C O O}=$ $-k_{B} T \ln K$, we calculate the equilibrium constant to be $K=1.1 \times 10^{4}$. With this large equilibrium constant, we expect that almost all the CBCA molecules in the LC mixture will adsorb on the Au surface by replacing 5CB. Thus, we calculate an equilibrium constant of $1.1 \times 10^{4}$ from the BE difference, suggesting complete coverage of $\mathrm{PhCOO}$ on $\mathrm{Au}(111)$ based on thermodynamic arguments.

To further elucidate on the coverage of CBCA-derived carboxylate in our experimental setup, we estimate the total number of CBCA molecules and exposed gold atoms in a square pore of a TEM grid, which is used as a container of LC film in our experiments (see description in Materials section) and shown in Figure $6 \mathrm{a}, \mathrm{S} 2$, and S3. We calculate the total surface area of gold to be $8.12 \times 10^{10} \mathrm{~nm}^{2}$ in a $285 \mu \mathrm{m} \times 285 \mu \mathrm{m}$ square pore. If we assume the most stable $\mathrm{Au}(111)$ surface for the whole gold surface, which should be the dominant surface facet, DFT calculations suggest that a $(3 \times 3)$ unit cell with 9 surface atoms covers 0.66 $\mathrm{nm}^{2}$. Thus, there are $1.10 \times 10^{12}$ gold atoms exposed on the gold surface in a square pore. From the volume of the square pore $\left(1.46 \times 10^{-6} \mathrm{~mL}\right)$, we can calculate the total number of CBCA molecules in a square pore to be $7.11 \times 10^{10}$ using the average molecular weight of $5 \mathrm{CB}(249.36 \mathrm{~g} / \mathrm{mol})$, the density of the LC mixture $(1.008 \mathrm{~g} / \mathrm{mL})$ and the concentration of CBCA $(0.002 \mathrm{~mol} \%)$. Therefore, if we assume that all CBCA molecules are on the surface, we calculate a $7.11 \times 10^{10} / 1.10 \times 10^{12}=0.07$ ML surface coverage of CBCAderived carboxylate.

Overall, we conclude that CBCA-derived carboxylate should cover the gold surface because of the large equilibrium constant, but the total amount of CBCA-derived carboxylate is so low in the experiments with $0.002 \mathrm{~mol} \% \mathrm{CBCA}$ that even when all $\mathrm{CBCA}$ are segregated to the surface, they can only form a submonolayer coverage.

(a)

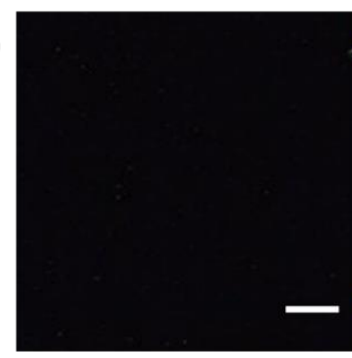

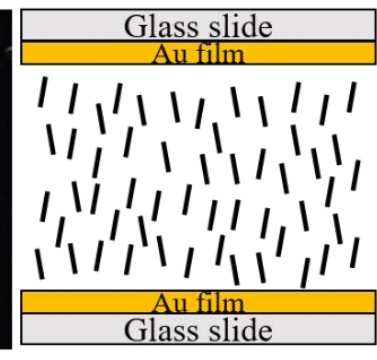

(b)

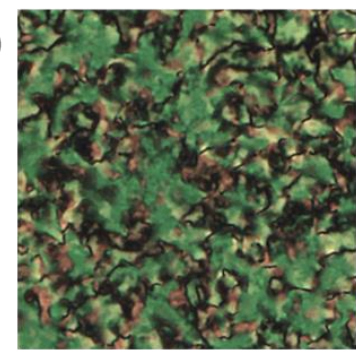

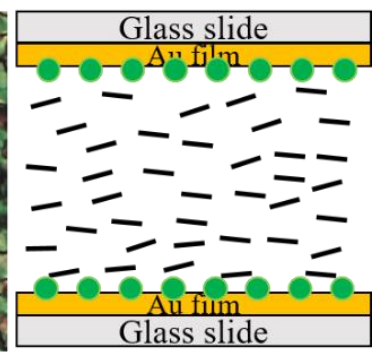

Figure S11. Optical micrographs (crossed polars) of LC films comprising of (a) $\mathrm{Cl}_{2}$ exposed CBCA-5CB $\left(C_{\mathrm{CBCA}}=0.002 \mathrm{~mol} \%\right)$ supported on gold surface and (b) $\mathrm{CBCA}-5 \mathrm{CB}\left(C_{\mathrm{CBCA}}=0.002 \mathrm{~mol} \%\right)$ supported on $\mathrm{Cl}_{2}$-absorbed gold surface. A schematic representation of the LCs is shown to the side of each optical image. Black lines indicate the director of LCs. Green circles represent $\mathrm{Cl}$ atoms. Scale bar: $100 \mu \mathrm{m}$.

Table S1. $\mathrm{T}_{\mathrm{NI}}$ of 5CB-CBCA mixtures before and after exposed to a gaseous $1 \mathrm{ppm} \mathrm{Cl}_{2}$

\begin{tabular}{llll}
\hline$C_{\mathrm{CBCA}}$ in $5 \mathrm{CB}(\mathrm{mol} \%)$ & 0 & 0.002 & 0.005 \\
\hline $\mathrm{T}_{\mathrm{NI}}$ before exposure $\left({ }^{\circ} \mathrm{C}\right)$ & 35.5 & 35.5 & 35.5 \\
$\mathrm{~T}_{\mathrm{NI}}$ at 60 mins $\left({ }^{\circ} \mathrm{C}\right)$ & 35.5 & 35.5 & 35.5 \\
\hline
\end{tabular}


Evaluation of the orientation of thin film of pure CBCA supported on a gold film after exposure to $\mathbf{C l}_{2}$. We exposed a thin film ( 2nm) of pure CBCA supported on a gold film to a nitrogen stream containing $1 \mathrm{ppm} \mathrm{Cl} \mathrm{C}_{2}$ for $30 \mathrm{mins}$ at $80{ }^{\circ} \mathrm{C}$. After exposure, we found the infrared spectrum to be indistinguishable from Figure 3b, I and 3d, I. This result reveals that a monolayer of pure CBCA does not react and reorganize with $\mathrm{Cl}_{2}$ in the same way as mixed films of $5 \mathrm{CB}$ and $\mathrm{CBCA}$ supported on gold. We note that the melting temperature of pure $\mathrm{CBCA}$ is much higher than the $\mathrm{CBCA}$ and $5 \mathrm{CB}$ mixture used in the experiments reported in the main text.
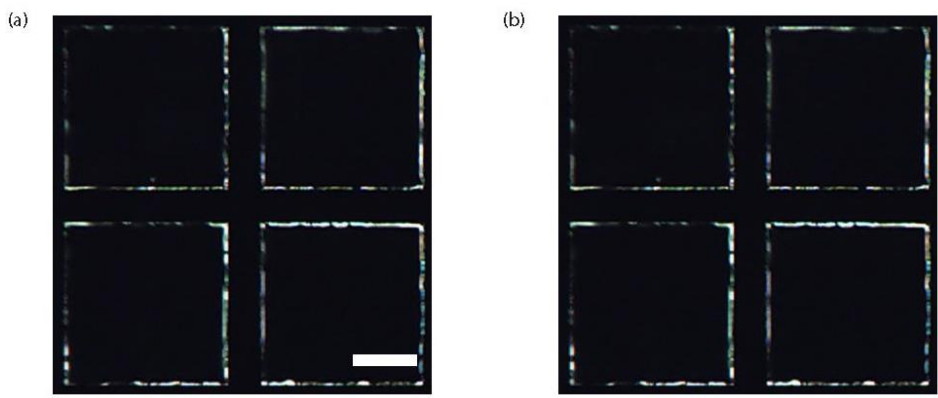

Figure S12. Optical micrographs (crossed polars) of LCs comprising of 5CB-CBCA $\left(C_{\mathrm{CBCA}}=0.002 \mathrm{~mol} \%\right)$ (a) before exposure and (b) after exposure to a vapor of $80 \% \mathrm{RH} \mathrm{N}_{2}, 5 \mathrm{ppm} \mathrm{NH}_{3}, 5 \mathrm{ppm} \mathrm{DMMP}$ or $5 \mathrm{ppm}$ Ethylene oxide for 1 hour. Scale bar: $100 \mu \mathrm{m}$.

Table S2. Binding energy of different interfering agents on clean Au(111) using a $(4 \times 4)$ unit cell. All energies are in $\mathrm{eV}$. Binding energy is defined relative to the gas-phase energy of the identical molecule (see details in Methods). Note that the binding energy of CBCA-derived carboxylate is $-1.15 \mathrm{eV}$ in $1 / 16$ coverage.

\begin{tabular}{lll}
\hline Molecule & Perpendicular & Coverage \\
\hline $\mathrm{N}_{2}$ & -0.11 & $1 / 16$ \\
$\mathrm{DMMP}$ & -0.61 & $1 / 16$ \\
$\mathrm{NH}_{3}$ & -0.59 & $1 / 16$ \\
$\begin{array}{l}\text { Ethylene- } \\
\text { oxide }\end{array}$ & -0.40 & $1 / 16$ \\
$\mathrm{HCHO}$ & -0.32 & $1 / 16$ \\
\hline
\end{tabular}

\section{Other principles for $\mathbf{C l}_{2}$ detection}

Previous studies have reported various principles and devices for the detection of chlorine gas. For example, metal oxide-based sensors, such as $\mathrm{CdSnO}_{3}{ }^{9}, \mathrm{In}_{2} \mathrm{O}_{3}{ }^{10}$ and $\mathrm{ZnO}^{11}$, have been reported to detect chlorine gas 
below $1 \mathrm{ppm}$. However, these require operation at temperatures above $100{ }^{\circ} \mathrm{C}$. In contrast, a Sb-doped $\mathrm{SnO}_{2}$ sensor ${ }^{11}$ has been reported to detect chlorine gas at room temperature, but it failed to detect chlorine gas below $1 \mathrm{ppm}$. Additionally, traditional sensors are expensive and not well-suited to use as wearable devices for measurement of human exposure to chemical environments.

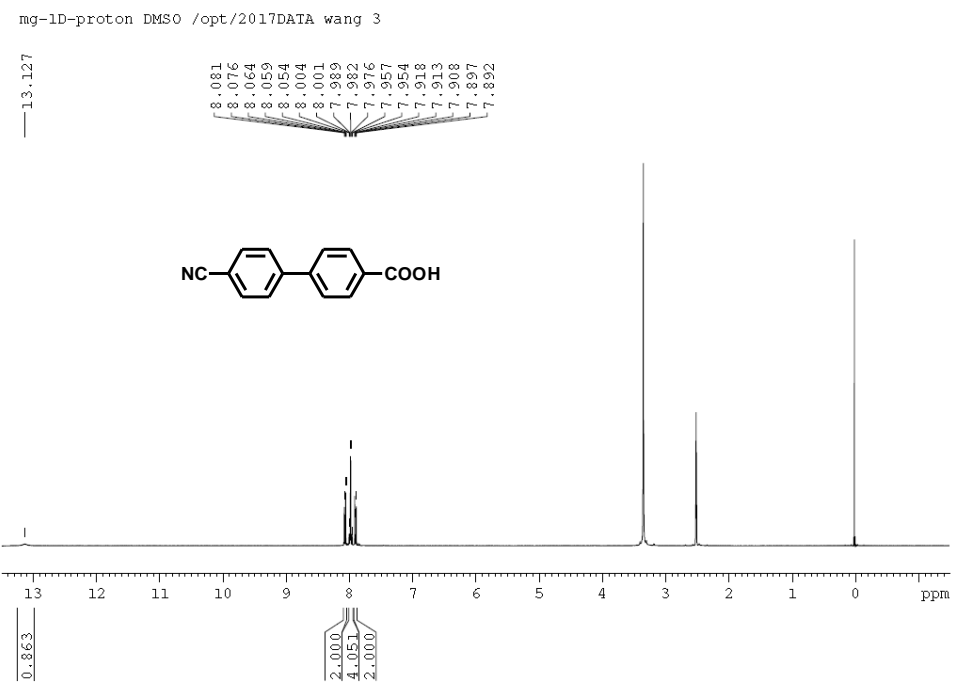

Figure S13. ${ }^{1} \mathrm{H}$ NMR spectrum of CBCA.

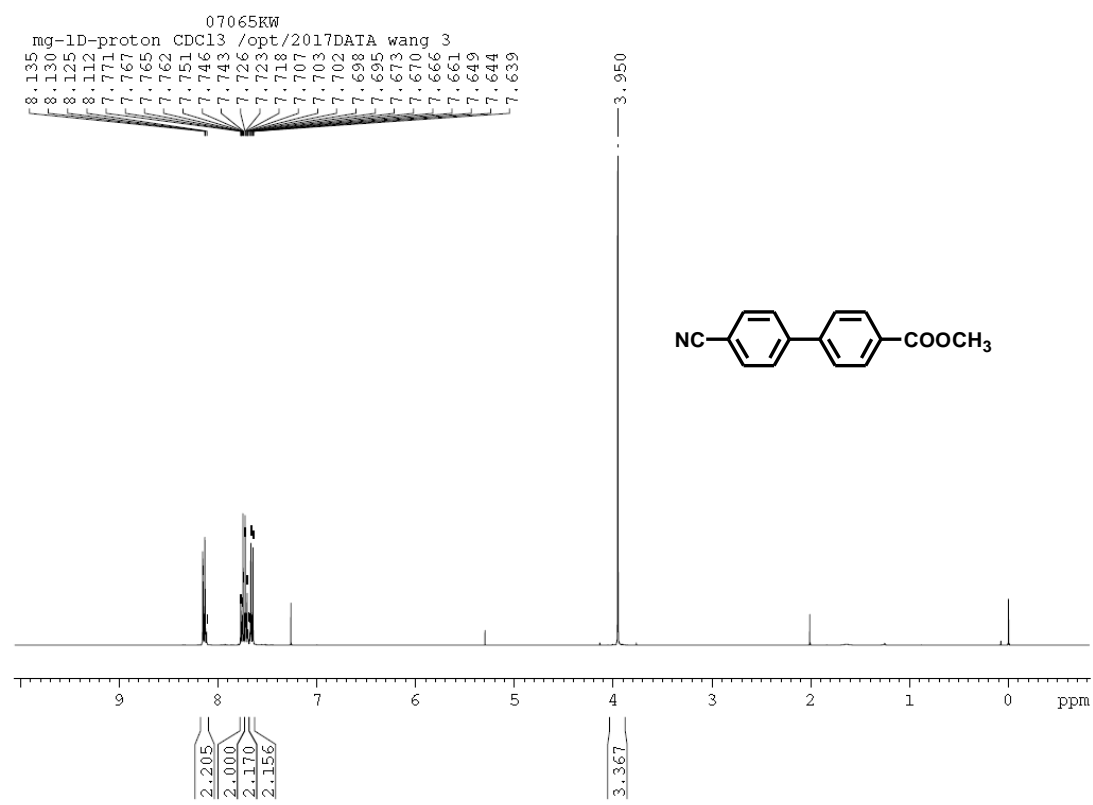

Figure S14. ${ }^{1} \mathrm{H}$ NMR spectrum of CBCM. 


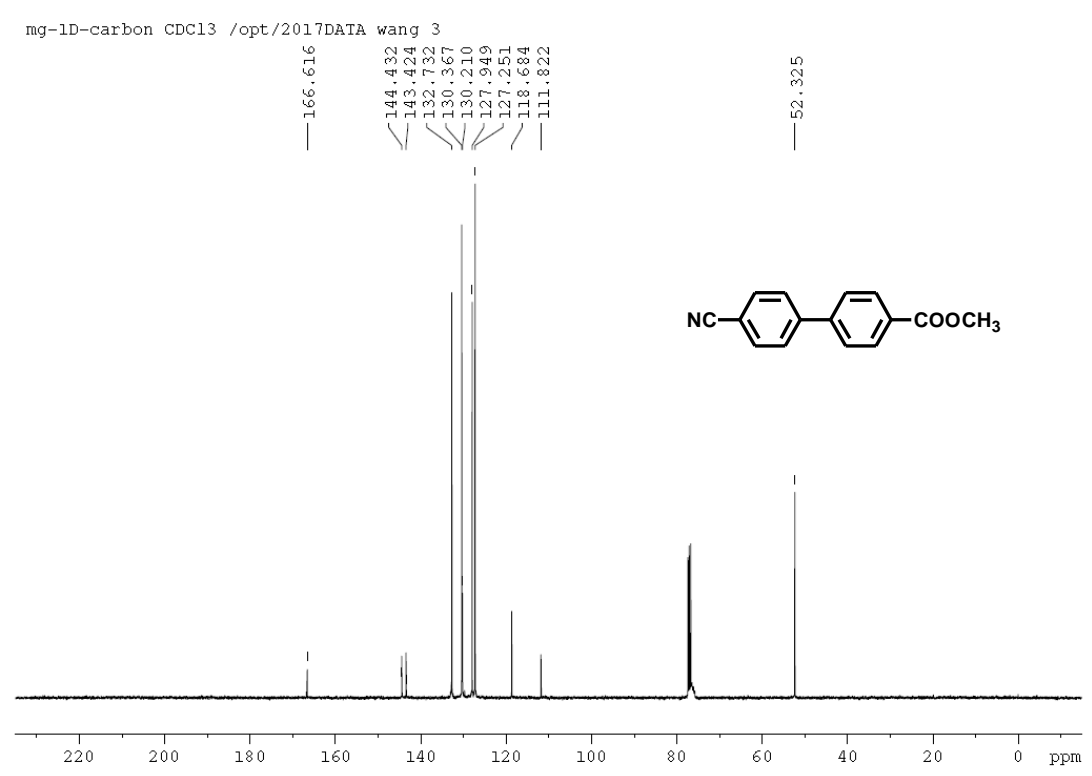

Figure S15. ${ }^{13} \mathrm{C}$ NMR spectrum of CBCM.

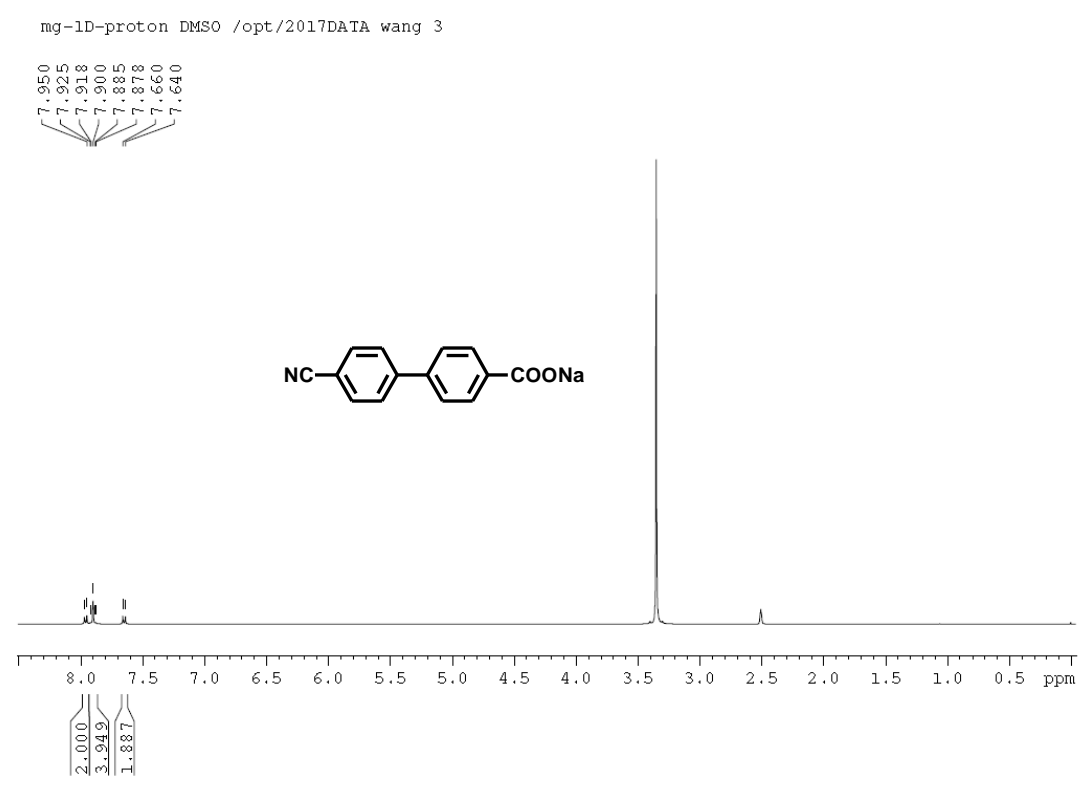

Figure S16. ${ }^{1} \mathrm{H}$ NMR spectrum of CBCNa. 


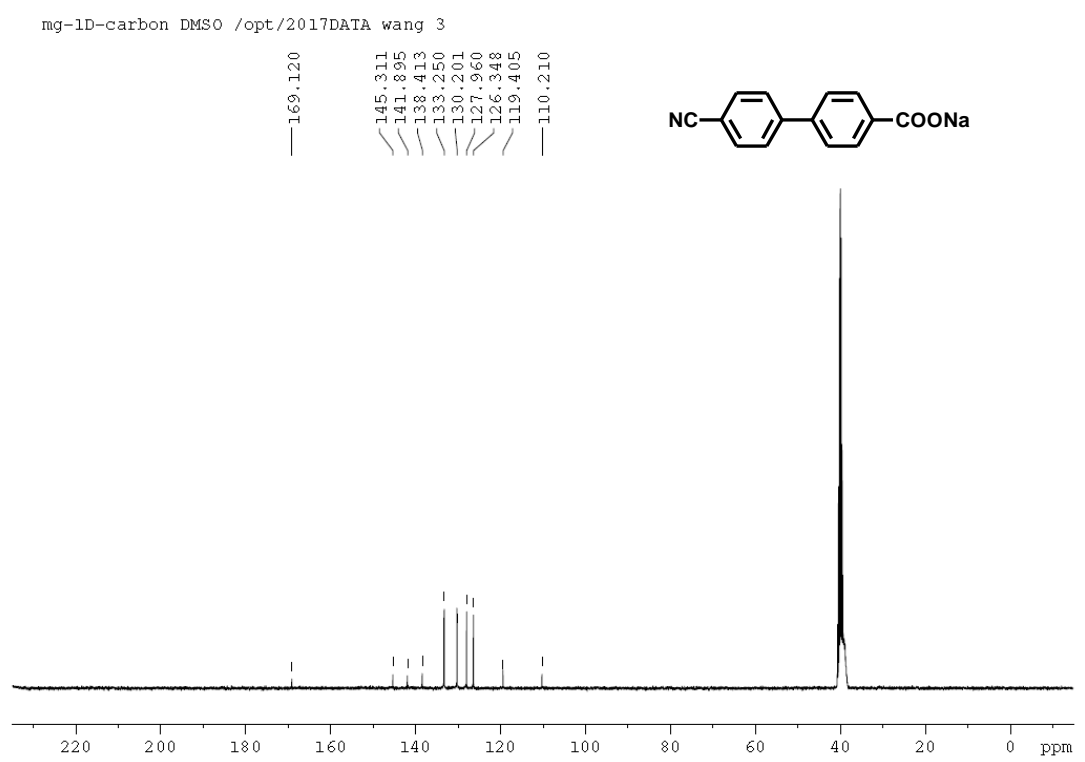

Figure S17. ${ }^{13} \mathrm{C}$ NMR spectrum of $\mathrm{CBCNa}$. 


\section{References}

(1) Bollinger, M. V; Jacobsen, K. W.; No, J. K.; Mos, E. Atomic and Electronic Structure of MoS2 Nanoparticles. 2003, No. June 2002, 1-17.

(2) Xu, L.; Stangland, E. E.; Mavrikakis, M. A DFT Study of Chlorine Coverage over Late Transition Metals and Its Implication on 1,2-Dichloroethane Hydrodechlorination. Catal. Sci. Technol. 2018, $8(6), 1555-1563$.

(3) Kastanas, G. N.; Koel, B. E. Interaction of Cl2 with the Au(111) Surface in the Temperature Range of 120 to 1000 K. Appl. Surf. Sci. 1993, 64 (3), 235-249.

(4) Gao, W.; Baker, T. A.; Zhou, L.; Pinnaduwage, D. S.; Kaxiras, E.; Friend, C. M. Chlorine Adsorption on $\mathrm{Au}(111)$ : Chlorine Overlayer or Surface Chloride? J. Am. Chem. Soc. 2008, 130 (11), 3560-3565.

(5) Zhang, P.; Bao, L.; Zuckett, J. F.; Goldman, E. A.; Jia, Z. J.; Arfsten, A.; Edwards, S.; Sinha, U.; Hutchaleelaha, A.; Park, G.; et al. Design , Synthesis , and SAR of Anthranilamide-Based Factor Xa Inhibitors Incorporating Substituted Biphenyl P4 Motifs. 2004, 14, 983-987.

(6) Byron, D. J.; Gray, G. W.; Wilson, R. C. The Synthesis of Some Substituted Biphenyl-4Carboxylic Acids, 4-Biphenylylacetic Acids, and 4-Aminobiphenyls. J. Chem. Soc. C Org. 1966, No. 840,840 .

(7) Ananthakrishnanadar, P.; Kannan, N. The Effects of Substituents on the Rate of Saponification of Biphenyl-4-Carboxylates. 1984, 35-37.

(8) Goossen, L. J.; Linder, C.; Rodríguez, N.; Lange, P. P. Biaryl and Aryl Ketone Synthesis via PdCatalyzed Decarboxylative Coupling of Carboxylate Salts with Aryl Triflates. 2009, 9336-9349.

(9) Xiangfeng, C. High Sensitivity Chlorine Gas Sensors Using CdSnO3 Thick Film Prepared by CoPrecipitation Method. Sensors Actuators B Chem. 2004, 98 (2-3), 215-217.

(10) Tamaki, J.; Niimi, J.; Ogura, S.; Konishi, S. Effect of Micro-Gap Electrode on Sensing Properties to Dilute Chlorine Gas of Indium Oxide Thin Film Microsensors. 2006, 117, 353-358.

(11) Chaparadza, A.; Rananavare, S. B. Room Temperature $\mathrm{Cl}_{2}$ Sensing Using Thick Nanoporous Films of Sb-Doped $\mathrm{SnO}_{2}$. Nanotechnology 2008, 19 (24), 245501. 